\title{
BMJ
}

\section{Effectiveness of interventions to promote physical activity in children and adolescents: systematic review of controlled trials}

\author{
Esther M F van Sluijs, investigator scientist, ${ }^{1}$ Alison M McMinn, PhD student, ${ }^{1}$ Simon J Griffin, group leader ${ }^{1}$
}

Medical Research Council Epidemiology Unit, Institute of Metabolic Sciences, Addenbrooke's Hospital, Cambridge CB2 OQQ

Correspondence to: EMFvan Sluijs esther.vansluijs@mrc-epid.cam.ac. uk

doi:10.1136/bmi.39320.843947.BE

\section{ABSTRACT}

Objective To review the published literature on the effectiveness of interventions to promote physical activity in children and adolescents.

Design Systematic review.

Data sources Literature search using PubMed, SCOPUS, Psychlit, Ovid Medline, Sportdiscus, and Embase up to December 2006.

Review methods Two independent reviewers assessed studies against the following inclusion criteria: controlled trial, comparison of intervention to promote physical activity with no intervention control condition, participants younger than 18 years, and reported statistical analyses of a physical activity outcome measure. Levels of evidence, accounting for methodological quality, were assessed for three types of intervention, five settings, and three target populations. Results The literature search identified 57 studies: 33 aimed at children and 24 at adolescents. Twenty four studies were of high methodological quality, including 13 studies in children. Interventions that were found to be effective achieved increases ranging from an additional 2. 6 minutes of physical education related physical activity to 283 minutes per week of overall physical activity. Among children, limited evidence for an effect was found for interventions targeting children from low socioeconomic populations, and environmental interventions. Strong evidence was found that school based interventions with involvement of the family or community and multicomponent interventions can increase physical activity in adolescents.

Conclusion Some evidence was found for potentially effective strategies to increase children's levels of physical activity. For adolescents, multicomponent interventions and interventions that included both school and family or community involvement have the potential to make important differences to levels of physical activity and should be promoted. A lack of high quality evaluations hampers conclusions concerning effectiveness, especially among children.

\section{INTRODUCTION}

The prevalence of childhood obesity and related health problems is increasing in many Western countries and is anticipated to continue to increase. ${ }^{1}$
Evidence of an association between physical activity and weight gain remains sparse. ${ }^{2}$ Nevertheless, in an effort to halt or reverse trends in obesity, promotion of physical activity in children and adolescents has been identified as a key focus of efforts to promote health. ${ }^{3-5}$ Physical activity among children and adolescents is believed to be insufficient, ${ }^{6-8}$ and low levels of activity seem to persist into adulthood. ${ }^{910}$ This makes physical inactivity among young people a risk factor for cardiovascular disease, cancer, and osteoporosis in later life. ${ }^{11}$ The development and evaluation of interventions to promote physical activity in young people is therefore a priority.

It is unclear how successful efforts have been to increase the activity levels of young people. Recently published reviews have mostly dealt with the prevention of obesity ${ }^{212-14}$ or included only adult populations. ${ }^{15-17}$ Previous attempts to summarise the evidence in young people were mostly narrative, ${ }^{18-20}$ did not assess the effects on children and adolescents separately, ${ }^{19-21}$ and did not assess the methodological quality of the studies. ${ }^{18-22}$ In addition these reviews have included studies without a no intervention control group ${ }^{18-21}$ and studies in which the promotion of physical activity was only a small part of an overall health promotion programme. ${ }^{18-22}$ We systematically reviewed the evidence on promotion of physical activity in children and adolescents.

\section{METHODS}

We carried out a literature search of papers on interventions to promote physical activity in young people using six electronic databases (Pubmed, Psychlit, SCOPUS, Ovid Medline, Sportdiscus, and Embase) from the year of their inception up to and including December 2006. The search strategy focused on four key elements: population (for example, youth, children), study design (for example, controlled trial, random), behaviour (for example, physical activity, walking, exercise), and intervention (for example, health education, behaviour change). (The full list of terms is available at www.mrc-epid.cam.ac.uk/Publica tions/Supplementary_Material/VanSluijsBMJ2007/.) We also carried out a citation search of included papers and published relevant reviews. ${ }^{21-14181921-30}$ Native 
speakers translated potentially relevant foreign language papers.

\section{Inclusion criteria}

We restricted the review to published trials, applying the following inclusion criteria: children and adolescents ( $\leq 18$ years), not selected on the basis of having a specific disease or health problem; interventions in which the main component or one of the components was aimed at promotion of physical activity through behaviour change in any setting (we excluded interventions to reduce sedentary behaviour, or structured exercise programmes to prevent obesity); inclusion of a non-physical activity intervention for the control group; and reported statistical analyses of an outcome measure related to physical activity (self reported or objectively measured).

Two reviewers (EMFvS, AMMcM) independently reviewed the results from the initial search of the title then the abstract and finally the full paper. When opinions differed consensus was reached through discussion.

\section{Assessment of methodological quality}

We assessed methodological quality using a 10 item quality assessment scale derived from previously used quality criteria ${ }^{13162931}$ and we focused on internal validity and analyses (table 1$)$. Two reviewers (EMFvS, $\mathrm{AMMcM}$ ) independently assessed for each study whether its score on an item was "positive," "negative," or "not, or insufficiently, described." In cases of disagreement, consensus was reached by discussion. We accumulated the positive scores and defined quality as high when a randomised controlled trial scored six or more or a controlled trial scored five or more. We analysed the level of agreement between the two reviewers using Cohen's $\kappa$, with agreement assessed on a dichotomous scale (negative and not described versus positive).

\section{Data extraction}

Data extraction on to standardised forms was undertaken separately for studies including children $(<12$ years, $A M M c M)$ and adolescents $(\geq 12$ years, EMFvS). We included interventions in high schools and American middle schools (6th to 8th grade, ages 11 to 14 ) in the adolescent category. Data extracted included project title, country, study design, inclusion criteria, baseline descriptive data, randomisation procedure, descriptions of intervention and control conditions, length of follow-up, losses to follow-up, selective drop out (observed differences between drop outs and study completers), physical activity measures used, secondary outcome measures, and results. In addition both reviewers (EMFvS, $\mathrm{AMMcM}$ ) extracted information on the specifics of the intervention (setting, target population, and intervention type), size of the baseline sample, and the overall effectiveness of the study for the main physical activity outcome measure (a measure of individual physical activity was used when available). We scored the size of the study as positive if there were more than 250 participants or if a power calculation was provided justifying the sample size (large) and as negative if there were 250 or fewer participants (small).

Studies used a wide range of methods to assess effectiveness and reported a variety of different outcome measures. We considered devising a common outcome metric for interpretational purposes, similar to a previous review focusing on interventions promoting one particular behaviour, walking. ${ }^{32}$ Although the studies included in this review assessed walking in different ways, it is a relatively homogeneous behaviour. In contrast, physical activity is more complex and consists of various domains, making it difficult to compare the results of the various measures used to assess this behaviour or particular sub-domains (for example, during breaks, out of school). Consequently because of the heterogeneity of the behaviour of interest and the outcome measures used we decided that calculating one common

\begin{tabular}{ll}
\hline $\begin{array}{l}\text { Table 1|Criteria for assessment of methodological quality } \\
\text { Item }\end{array}$ & $\begin{array}{l}\text { Gescription } \\
\text { at least one relevant outcome measure; for cluster randomised controlled trials and controlled trials, positive if this was statistically } \\
\text { tested; and for all studies only positive when differences observed were controlled for in analyses) }\end{array}$ \\
\hline B & Randomisation procedure clearly described and adequately carried out \\
\hline $\mathrm{C}$ & $\begin{array}{l}\text { Unit of analysis was individual (negative if unit of analysis was school level or school level randomisation not accounted for in } \\
\text { individual level analyses) }\end{array}$ \\
\hline $\mathrm{D}$ & Validated measures of physical activity used (positive if validation of measures of physical activity was reported or referred to) \\
\hline $\mathrm{E}$ & $\begin{array}{l}\text { Dropout described and not more than } 20 \% \text { for studies with follow-up of six months or shorter and 30\% for studies with follow-up of } \\
\text { more than six months }\end{array}$ \\
\hline $\mathrm{F}$ & Timing of measurements comparable between intervention and control groups \\
\hline $\mathrm{G}$ & $\begin{array}{l}\text { Blinding outcome assessment (positive if those responsible for assessing physical activity at outcome were blinded to group } \\
\text { allocation of individual participants) }\end{array}$ \\
\hline J & Participants followed up for a minimum of six months \\
\hline Intention to treat analysis used
\end{tabular}


Table 2 | Intervention characteristics of included studies aimed at increasing physical activity in children (named reference is main reference)

Study Design*; country Setting $\begin{gathered}\text { Target } \\ \text { population Participants }\end{gathered}$

Educational interventions:

\begin{tabular}{|c|c|c|c|c|}
\hline $\begin{array}{l}\text { Christodoulos } \\
2006^{\text {w1 }}\end{array}$ & $\begin{array}{l}\text { Randomised } \\
\text { controlled trial } \\
\text { (school); Greece }\end{array}$ & School plus† & None & $\begin{array}{l}n=78 \text {; mean age } \\
11.2 \text { (SD 0.4) } \\
\text { years; } 54 \% \text { boys }\end{array}$ \\
\hline
\end{tabular}

Intervention group: 1 year's duration, two 45 minute classes of physical education per week. Focus on cooperative activities, including individual goal setting and three minute talk on physical activity and health. Weekly classroom lecture with focus on physical activity knowledge and health education integrated into other subjects. Physical education teachers and classroom teachers received training. Children got homework assignments with family activities; parents received educational material and were advised to encourage children to incorporate physical activity into daily lives. Control group: usual physical education programme, two 45 minute classes per week

\begin{tabular}{|c|c|c|c|c|}
\hline $\begin{array}{l}\text { Fitzgibbon } \\
2006^{\text {w2 }} \text { (Hip- } \\
\text { hop to health Jr) }\end{array}$ & $\begin{array}{l}\text { Randomised } \\
\text { controlled trial } \\
\text { (school); USA }\end{array}$ & School plust & Ethnic minority & $\begin{array}{l}\mathrm{n}=401 \text {; mean age } \\
51 \text { (SD } 7) \text { months; } \\
50 \% \text { girls; } 81 \% \\
\text { Latino }\end{array}$ \\
\hline
\end{tabular}
Intervention group: 14 weeks' duration, three 40 minute sessions per week. Focus on healthy eating and exercise, specific topics changed each week. Each session included 20 minutes to introduce new topic and 20 minutes' physical activity. Parents received weekly newsletter to match curriculum, including homework assignment. Control group: "general health" intervention for 14 weeks, no information on diet or physical activity included, one 20 minute session per week

Harrison $2006^{\text {w3 }}$ Controlled trial School plust Low SES

(Switch off-get (school); Ireland

$\mathrm{n}=312$; mean age

10.2 (SD 1.0)

active) years; $43 \%$ girls

Intervention group: 16 weeks' duration, ten 30 minute lessons. Focus on minimising television and computer use and increasing physical activity. Health education approach targeting self esteem, decision making skills, self reflection, and personal development. Included self monitoring, budgeting, and goal setting techniques. Parents encouraged to support children and to verify children's behaviour. Control group: usual curriculum

\begin{tabular}{|c|c|c|c|c|}
\hline $\begin{array}{l}\text { Manios } \\
2006^{\text {w4-w7 }}\end{array}$ & $\begin{array}{l}\text { Controlled trial } \\
\text { (area); Greece }\end{array}$ & School plust & None & $\begin{array}{l}\mathrm{n}=1046 \\
\text { (subsample of } \\
579 \text { selected for } \\
\text { cohort analyses); } \\
\text { aged 5.5-6. }\end{array}$ \\
\hline
\end{tabular}

Intervention group: 6 years' duration. Health and nutrition component (13-17 hours over academic year), physical fitness, and activity component ( $2 \times 45$ minute physical education sessions per week and 4-6 hours of classroom sessions per year), and homework. Parents given booklets on nutrition and physical activity. Control group: standard physical education classes.

\begin{tabular}{|c|c|c|c|c|}
\hline $\begin{array}{l}\text { Fairclough } \\
2005^{\text {w8-w9 }}\end{array}$ & $\begin{array}{l}\text { Randomised } \\
\text { controlled trial } \\
\text { (class); UK }\end{array}$ & School-only & One sex & $\begin{array}{l}\mathrm{n}=33, \text { mean age } \\
12.4 \text { (SD } 0.4) \\
\text { years, girls only }\end{array}$ \\
\hline $\begin{array}{l}\text { Fitzgibbon } \\
2005^{\mathrm{w} 10} \text { (Hip- } \\
\text { hop to health Jr) }\end{array}$ & $\begin{array}{l}\text { Randomised } \\
\text { controlled trial } \\
\text { (school); USA }\end{array}$ & School plust & Ethnic minority & $\begin{array}{l}\mathrm{n}=409 ; \text { mean age } \\
49.7 \text { (SD 7.0) } \\
\text { months; } 50 \% \\
\text { girls; about } 90 \% \\
\text { African-American }\end{array}$ \\
\hline $\begin{array}{l}\text { French, } 2005^{\text {w11 }} \\
\text { (Cal-girls) }\end{array}$ & $\begin{array}{l}\text { Randomised } \\
\text { controlled trial } \\
\text { (girl scout troop); } \\
\text { USA }\end{array}$ & Community & One sex & $\begin{array}{l}n=322 ; \text { mean age } \\
10.5 \text { years; girls } \\
\text { only }\end{array}$ \\
\hline
\end{tabular}

Intervention group: 5 weeks' duration, curriculum based. Weekly two hour physical education classes taught by usual physical education teacher. Teacher given objectives to work by to increase physical activity during class. Control group: usual curriculum

Intervention group: 14 weeks' duration, three 40 minute sessions per week. Focus on healthy eating and exercise, specific topics changed each week. Each session included 20 minutes to introduce new topic and 20 minutes' physical activity. Parents received weekly newsletters to match curriculum, including homework assignment. Control group: "general health" intervention for 14 weeks, no information on diet or physical activity included. Weekly 20 minute sessions and newsletter

Intervention group: 2 years' duration, ten 90 minute sessions in each year at troop meetings. Focus on developing behavioural skills to choose calcium rich foods and engage in weightbearing physical activity. Included group goal setting, interactive web based programme, and summer camp for one week. Parents also targeted through web based programme. Troop leaders received training and delivered intervention. Control group: usual troop meeting activities

\begin{tabular}{|c|c|c|c|c|}
\hline $\begin{array}{l}\text { Kelder } 2005^{\mathrm{w} 12} \\
\text { (CATCH Kid's } \\
\text { Club) }\end{array}$ & $\begin{array}{l}\text { Controlled trial } \\
\text { (school); USA }\end{array}$ & School only & None & $\begin{array}{l}n=258, \text { mean age } \\
9 \text { years; both } \\
\text { sexes } \neq\end{array}$ \\
\hline
\end{tabular}

Intervention group 1: 5 months' duration. Physical activity component aimed to involve students in 30 or more minutes of daily physical activity, at least $40 \%$ of which should be MVPA, and to provide students with opportunities to practise physical activity skills to carry over to other times of day. Staff given training and "activity box." Intervention group 2: as above, plus education and snack components, consisting of nutrition activities, modules on health food choices, and increasing MVPA at school and home. Control group: no intervention

\begin{tabular}{|c|c|c|c|c|}
\hline $\begin{array}{l}\text { Palmer } 2005^{\text {w13 }} \\
\text { (Healthy hearts } \\
4 \text { kids) }\end{array}$ & $\begin{array}{l}\text { Controlled trial } \\
\text { (class); USA }\end{array}$ & School only & None & $\begin{array}{l}\mathrm{n}=233 ; 5 \text { th grade } \\
\text { children; } 44 \% \\
\text { boys }\end{array}$ \\
\hline
\end{tabular}

Intervention group: 1 month's duration. Web based programme consisting of units on cardiovascular function, physical activity, nutrition, and tobacco. Sessions twice a week in computer lab, each lasting up to 50 minutes. Online activities include quizzes, information (such as benefits, physical activity recommendations, how to participate in physical activity), and reporting physical activity and nutrition habits. Participants also received feedback on their reported physical activity. Control group: received above intervention after one month (comparison made before control group started intervention)

\begin{tabular}{|c|c|c|c|c|c|}
\hline $\begin{array}{l}\text { Sääkslahti } \\
2004^{\text {w14 }} \text { (part of } \\
\text { STRIP) }\end{array}$ & $\begin{array}{l}\text { Controlled trial } \\
\text { (family); Finland }\end{array}$ & Family & None & $\begin{array}{l}\mathrm{n}=228 ; \text { mean age } \\
4.5 \text { (SD } 0.5) \text { years; } \\
48 \% \text { boys in } \\
\text { intervention } \\
\text { group, } 55 \% \text { boys } \\
\text { in control group }\end{array}$ & $\begin{array}{l}\text { Intervention group: } 3 \text { years' duration. Annual one hour sessions held with parents, } \\
\text { covering importance of sensory integration, motivation through providing information } \\
\text { on physical activity and health and previous intervention studies, and options for } \\
\text { children's physical activity in Turku. Parents also received printed material twice a year } \\
\text { including activity posters, a special physical activity board game, and review articles. } \\
\text { Control group: no intervention }\end{array}$ \\
\hline $\begin{array}{l}\text { Baranowski } \\
2003^{\text {w15 }} \text { (GEMS } \\
\text { FFFP) }\end{array}$ & $\begin{array}{l}\text { Randomised } \\
\text { controlled trial } \\
\text { (individual), pilot } \\
\text { study; USA }\end{array}$ & Community & $\begin{array}{l}\text { Ethnic minority \& } \\
\text { one gender }\end{array}$ & $\begin{array}{l}\mathrm{n}=35 \text { (child and } \\
\text { family), age } \\
8 \text { years; African- } \\
\text { American girls } \\
\text { only }\end{array}$ & $\begin{array}{l}\text { Intervention group: summer camp for } 4 \text { weeks plus } 8 \text { weeks of internet programme at } \\
\text { home. Camp mixed usual activities with interactive activities to promote intake of fruit } \\
\text { and vegetables and physical activity, including decision making, problem solving, and } \\
\text { goal setting. Participants asked to log on to internet programme once a week after } \\
\text { summer camp. Control group: summer camp for } 4 \text { weeks, containing usual camp } \\
\text { activities only. Internet programme contained links to general health and homework } \\
\text { websites. Participants asked to log on once a month }\end{array}$ \\
\hline
\end{tabular}


Randomised Family study; USA
Beech $2003^{\text {w16 }}$ (Memphis GEMS) controlled trial (individual); pilot
Ethnic minority and one sex $\mathrm{n}=60$; mean age 8.9 (SD 0.8) years; African-American girls only; at or above 25th centile of age and sex specific body mass index

Ethnic minority $\quad n=43$; aged

9 months to

3 years; $54 \%$

boys; Native

American

community.

Mother's body mass index $>25$

\begin{tabular}{|c|c|c|c|c|}
\hline $\begin{array}{l}\text { Pangrazi } \\
2003^{w 18} \text { (PLAY) }\end{array}$ & $\begin{array}{l}\text { Controlled trial } \\
\text { (school); USA }\end{array}$ & School only & None & $\begin{array}{l}n=606 ; \text { mean age } \\
9.8 \text { (SD 0.6) years; } \\
52 \% \text { boys }\end{array}$ \\
\hline
\end{tabular}

ntervention group 1: child targeted: 12 weeks' duration. Focus on nutrition and physical activity. Weekly 90 minute session covering aerobics, reducing sedentary activity, and promoting intake of fruit and vegetables and other healthy diet practices. Intervention group 2: parent targeted: 12 weeks' duration. Weekly 90 minute session. Physical activity component focused on dancing; other components included nutrition, food preparation, and nutrition related games. Control group: 12 weeks' duration. $3 \times$ 90 minute sessions per month. Focus on self esteem; neutral for diet and physical activity Intervention group: obesity prevention and parenting support (OPPS) programme, 16 weeks' duration. Eleven sessions carried out at participants' homes, run by indigenous peer educator. Focus exclusively on parenting skills for improving eating and exercise behaviours in children. Control group: parenting support programme. Same setup as intervention but educator instructed to refrain from discussing child or parent eating and exercise behaviours

Intervention group 1: impact of promoting lifestyle activity for youth (PLAY) programme and physical education: 12 weeks' duration. Usual physical education programme plus daily sessions, with class teachers facilitating 15 minutes of physical activity. Focus moved from teachers prompting activity to encouraging children to be self directed. Students kept log book of physical activity outside school. Intervention group 2: PLAY only: as above but did not include physical education programme. Control group 1 : physical education only: usual physical education programme only, for 12 weeks. Students kept log book of activities outside school (sedentary and physical activities). Control group 2: no treatment: no PLAY or physical education programme. Students kept log book as above

\begin{tabular}{|c|c|c|c|c|}
\hline $\begin{array}{l}\text { Story } 2003^{\text {w19 }} \\
\text { (Girlfriends for } \\
\text { KEEPS) }\end{array}$ & $\begin{array}{l}\text { Randomised } \\
\text { controlled trial } \\
\text { (individual); pilot } \\
\text { study; USA }\end{array}$ & School plust & $\begin{array}{l}\text { Ethnic minority } \\
\text { and one sex }\end{array}$ & $\begin{array}{l}\mathrm{n}=54, \text { mean age } \\
9.3 \text { (SD 0.9) years, } \\
\text { girls only, African- } \\
\text { American }\end{array}$ \\
\hline
\end{tabular}

Intervention group: 12 weeks' duration. Two after school club sessions per week, focusing on healthy eating; increasing frequency of physical activity; decreasing time in sedentary activity; and experiencing feeling enjoyment, competence, and confidence; also had weekly take home packs for family, two family nights, and two phone calls a week. Control group: after school club, with no diet or physical activity information (three sessions over 12 weeks)

\begin{tabular}{|c|c|c|c|c|}
\hline $\begin{array}{l}\text { Warren, } \\
2003^{\mathrm{w} 20}(\mathrm{Be} \\
\text { Smart) }\end{array}$ & $\begin{array}{l}\text { Randomised } \\
\text { controlled trial } \\
\text { (individual); UK }\end{array}$ & School plust & None & $\begin{array}{l}n=218 ; \text { mean age } \\
6.1 \text { (SD 0.6) years; } \\
51 \% \text { boys }\end{array}$ \\
\hline
\end{tabular}

\begin{tabular}{|c|c|c|c|c|}
\hline $\begin{array}{l}\text { Harrell, } 1996^{\text {w21 }} \\
\text { (CHIC) }\end{array}$ & $\begin{array}{l}\text { Randomised } \\
\text { controlled trial } \\
\text { (school); USA }\end{array}$ & School only & None & $\begin{array}{l}n=1274 ; \text { mean } \\
\text { age } 8.9(S D 0.8) \\
\text { years; } 48 \% \text { boys }\end{array}$ \\
\hline
\end{tabular}

\begin{tabular}{|c|c|c|c|c|}
\hline $\begin{array}{l}\text { Howard } \\
1996^{\text {w22 }}\end{array}$ & $\begin{array}{l}\text { Controlled trial } \\
\text { (class); USA }\end{array}$ & School only & None & $\begin{array}{l}\mathrm{n}=96 \text {; mean age } \\
10.4 \text { (SD } 0.99 \text { ) } \\
\text { years; } 54 \% \text { boys }\end{array}$ \\
\hline
\end{tabular}

\begin{tabular}{|c|c|c|c|c|c|}
\hline $\begin{array}{l}\text { Baranowski } \\
1990^{\text {w23 }}\end{array}$ & $\begin{array}{l}\text { Randomised } \\
\text { controlled trial } \\
\text { (family); USA }\end{array}$ & Family & Ethnic minority & $\begin{array}{l}\mathrm{n}=120 \text { ( } 94 \\
\text { families); mean } \\
\text { age, intervention } \\
\text { group } 10.6 \text { years, } \\
\text { control group, } \\
\text { 10.9; } 48 \% \text { boys in } \\
\text { intervention } \\
\text { group, } 34 \% \text { in } \\
\text { control group; } \\
\text { Black-American }\end{array}$ & $\begin{array}{l}\text { Intervention group: } 14 \text { weeks' duration; one education and two fitness centre sessions } \\
\text { per week. Education sessions lasted } 90 \text { minutes and included behavioural counselling } \\
\text { small group education, aerobic activity, and health snack components. (Small group } \\
\text { education dropped after } 7 \text { weeks.) At fitness sessions, participants required to focus or } \\
\text { one activity for training. Control group: no contact made for duration of intervention }\end{array}$ \\
\hline
\end{tabular}

Environmental interventions:

vironmental interventions:

\begin{tabular}{|c|c|c|c|c|c|}
\hline $\begin{array}{l}\text { Verstraete } \\
2006^{\mathrm{w} 24}\end{array}$ & $\begin{array}{l}\text { Randomised } \\
\text { controlled trial } \\
\text { (school), Belgium }\end{array}$ & School only & None & $\begin{array}{l}\mathrm{n}=249 ; \text { mean age } \\
10.8 \text { (SD } 0.7) \\
\text { years; } 51 \% \text { boys }\end{array}$ & $\begin{array}{l}\text { Intervention group: } 3 \text { months' duration. Classes provided with game equipment and } \\
\text { activity cards with examples of games and activities. Teachers asked to encourage } \\
\text { children daily to play with equipment during morning, lunch, and afternoon breaks. } \\
\text { Control group: no provision of equipment or cards }\end{array}$ \\
\hline $\begin{array}{l}\text { Stratton } \\
2005^{\mathrm{w} 25}\end{array}$ & $\begin{array}{l}\text { Controlled trial } \\
\text { (area); UK }\end{array}$ & School only & None & $\begin{array}{l}n=120 ; \text { aged } \\
4-11 \text { years; } 50 \% \\
\text { boys }\end{array}$ & $\begin{array}{l}\text { Intervention group: playground painted during school holidays according to school } \\
\text { preference to encourage play. Also small pieces of sports equipment allowed in } \\
\text { playgrounds. Control group: no playground markings but small pieces of sports } \\
\text { equipment allowed in playground }\end{array}$ \\
\hline $\begin{array}{l}\text { Stratton } \\
2002^{\text {w26 }}\end{array}$ & $\begin{array}{l}\text { Randomised } \\
\text { controlled trial } \\
\text { (school); UK }\end{array}$ & School only & None & $\begin{array}{l}n=60 ; 5-7 \text { years; } \\
50 \% \text { boys }\end{array}$ & $\begin{array}{l}\text { Intervention group: painted playground markings to encourage play. Control group: no } \\
\text { playground markings }\end{array}$ \\
\hline $\begin{array}{l}\text { Stratton } \\
2000^{\mathrm{w} 27}\end{array}$ & $\begin{array}{l}\text { Controlled trial } \\
\text { (school); UK }\end{array}$ & School only & None & $\begin{array}{l}n=60 ; \text { aged } \\
5-7 \text { years; } 50 \% \\
\text { boys }\end{array}$ & $\begin{array}{l}\text { Intervention group: playground painted according to children's designs to encourage } \\
\text { play. Children also allowed a football in playground but no other play equipment. } \\
\text { Control group: no playground markings but allowed limited equipment into playground }\end{array}$ \\
\hline $\begin{array}{l}\text { Jurg } 2006^{\mathrm{w} 28} \\
\text { (JUMP-in) }\end{array}$ & & School plust & Low SES & $\begin{array}{l}n=510 ; \text { grades } 4- \\
6 \text { ( } 9-12 \text { years); }\end{array}$ & $\begin{array}{l}\text { Intervention group: } 6 \text { years' duration (this paper reports results at } 1 \text { year). Composed of } \\
\text { six programme components: school sports activities (during and after school), pupil }\end{array}$ \\
\hline
\end{tabular}


Controlled trial (city district); Netherlands
$48.5 \%$ boys $; 71 \%$ follow-up system (yearly monitoring of pupils' physical activity levels by physical of intervention education teacher), in-class exercises, lessons on awareness, parental information group and $94 \%$ of services, and an activity week (once a year, involving parents, the schools, and local control group of sports clubs). Control group: usual curriculum

foreign origin $(\mathrm{P}<0.01)$

\begin{tabular}{|c|c|c|c|c|}
\hline Reilly $2006^{\text {w29 }}$ & $\begin{array}{l}\text { Randomised } \\
\text { controlled trial } \\
\text { (nursery); UK }\end{array}$ & School plust & None & $\begin{array}{l}\mathrm{n}=545 ; \text { mean age } \\
4.2 \text { (SD } 0.3 \text { years); } \\
50 \% \text { boys }\end{array}$ \\
\hline
\end{tabular}
guidance on linking physical activity at nursery and home and opportunities for increasing physical activity and reducing time spent watching television. Control group: usual curriculum

$\begin{array}{lllll}\text { Coleman } & \text { Controlled trial } & \text { School only } & \text { Ethnic minority } & \mathrm{n}=896 \text {; aged } \\ 2005^{\mathrm{w} 30}(\mathrm{El} & \text { (school); USA } & & \text { and low SES } & \begin{array}{l}8-9 \text { years, } 52 \% \\ \text { boys }\end{array} \\ \text { Paso CATCH }) & & & \end{array}$

\begin{tabular}{llll}
\hline $\begin{array}{l}\text { Paradis } \\
2005^{\text {w31 w32 }} \\
\text { (KSDPP) }\end{array}$ & $\begin{array}{l}\text { Controlled trial } \\
\text { (area); Canada }\end{array}$ & School plust & None \\
& & \\
& & \\
\hline $\begin{array}{l}\text { Caballero, } \\
2003^{\text {w33-w36 }}\end{array}$ & $\begin{array}{l}\text { Randomised } \\
\text { (Pathways) }\end{array}$ & School plust & Ethnic minority \\
& (school); USA & & \\
& & &
\end{tabular}

$n=443$, aged 6-7 years (for longitudinal comparison); both sexesł; Native American community age 7.6 (SD 0.6) years; $52 \%$ boys Native American

Intervention group: 3 year curriculum based intervention consisting of El Paso coordinated approach to child health (CATCH) physical education classes, Eat Smart, classroom curriculum, and home team components (implemented in stages). Schools given funding for physical education equipment, training staff for intervention and promotion of CATCH. Control group: also received funding (although lesser amount) as incentive to participate. Schools received summary results after one year. Otherwise usual curriculum

Intervention group: 6 years' duration (grades 1-6), consisting of ten 45 minute sessions per year for each grade. Curriculum included type 2 diabetes, nutrition, physical activity and fitness, and other healthy lifestyles. Also had community activities, ban on junk food at school, and construction of walking and cycling paths in the community. Control group: non-equivalent comparison group

Intervention group: 3 years' duration (grades 3-5). Included classroom curriculum (two lessons per week for 12 weeks in grades 3 and 4, 8 weeks in grade 5), physical activity (minimum of three 30 minute sessions per week of MVPA), family involvement (nine events at school plus information sent home), and changes to food service (to promote healthy eating). Control group: usual curriculum

Pate $2003^{\text {w37 }} \quad$ Controlled trial School plust Ethnic minority

\begin{tabular}{|c|c|c|c|c|}
\hline $\begin{array}{l}\text { Van Beurden } \\
2003^{\text {w38 }} \text { (Move } \\
\text { it groove it) }\end{array}$ & $\begin{array}{l}\text { Controlled trial } \\
\text { (school); } \\
\text { Australia }\end{array}$ & School only & None & $\begin{array}{l}n=1045 ; \text { aged } \\
7-10 \text { years; } 53 \% \\
\text { boys }\end{array}$ \\
\hline
\end{tabular}

\begin{tabular}{|c|c|c|c|}
\hline $\begin{array}{l}\text { Sahota } \\
2001^{\text {w39-w40 }} \\
\text { (APPLES) }\end{array}$ & $\begin{array}{l}\text { Randomised } \\
\text { controlled trial } \\
\text { (school); UK }\end{array}$ & School only & None \\
\hline
\end{tabular}

\begin{tabular}{llll}
\hline Sallis & Randomised & School plust & None \\
$1997^{\text {w1-w43 }}$ & controlled trial & & \\
(SPARK) & (school); USA & &
\end{tabular}

\begin{tabular}{|c|c|c|c|c|}
\hline $\begin{array}{l}\text { McKenzie } \\
1996^{\text {w44-w47 }} \\
(\text { CATCH })\end{array}$ & $\begin{array}{l}\text { Randomised } \\
\text { controlled trial } \\
\text { (school); USA }\end{array}$ & School plust & None & $\begin{array}{l}n=5106 \text {; mean } \\
\text { age } 8.7 \text { years; } \\
52 \% \text { boys }\end{array}$ \\
\hline
\end{tabular}

$\mathrm{n}=436$; mean age 10.8 (SD 0.7) years; $49 \%$ boys; $87.4 \%$ AfricanAmerican in intervention group, $59.8 \%$ in control group

\section{Intervention group: 18 months' duration: 1 year of primary intervention, follow-up} activities for 6 months. Four components: active kids (after school and summer programme), active home (newsletter, home assignments, and family activity nights), active school (activities to make physical activity more accessible and attractive), active community (features in local newspaper and incorporation of physical activity into existing events). Control group: no intervention

Intervention group: 1 year's duration. Consisted of five strategies to support teachers and create supportive environments, and healthy school policies to improve fundamental movement skills and increase physical activity. Strategies were school project teams, buddy programme, professional development for teachers, project website, and funding for purchase of equipment. Control group: no intervention

$\mathrm{n}=636$; mean age Intervention group: one (academic) year's duration. Consisted of teacher training, 8.4 (SD 0.63) modifications of school meals, and development and implementation of school action years; $51 \%$ boys plans to promote healthy eating and physical activity. Control group: usual health in intervention curriculum group, $59 \%$ in control group

n=1538; mean age range 9.49 to 9.62 years in three study groups; $53 \%$ boys
Intervention group 1: 2 years' duration (grades 4 and 5). Specialist led physical education classes three 30 minute sessions per week and weekly self management session (30 minutes) to teach behaviour change skills to help generalise to regular physical activity outside school. Included homework and monthly newsletters. Specialists received ongoing training and supervision from investigators. Intervention group 2: as above but teacher led. Teachers received extensive in-service training programme, which decreased in frequency over the intervention group period. Also had consultations with physical education specialists, ranging from biweekly to bimonthly during the intervention group period. Control group: usual physical education programmes but schools provided with sufficient physical education equipment to carry out sports, play, and active recreation for kids (SPARK) programme, as with intervention schools

Intervention group 1: 3 years' duration (grades 3-5). School based programme: $\leq$ 90 minutes of CATCH physical education per week over a minimum of three sessions per week, taught by either physical education specialists or classroom teachers. Also food service modifications and CATCH curriculum focused on eating habits, physical activity, and smoking. Intervention group 2: school based and family based intervention; as above plus home activity curriculum and family fun nights. Control group: usual health curriculum, physical education, and food service programmes. Required to give $\leq$ 90 minutes of physical education over a minimum of three sessions per week

$\mathrm{SES}=$ socioeconomic status; $\mathrm{MVPA}=$ moderate-vigorous or vigorous physical activity.

* Level of randomisation or group allocation given in brackets.

†includes involvement of family or community.

$\ddagger$ No further descriptive data available on baseline sample. 
measure of outcome would not be valid or informative. Alternatively we used scores to indicate effectiveness - that is, whether there was no difference in effect between control and intervention group (0 score), a positive or negative trend (+ or - ), or a statistically significant difference $(\mathrm{P}<0.05)$ in favour of the intervention or control group $(++$ or - , respectively). In cases of disagreement, consensus was reached by discussion.

\section{Strength of the evidence}

We thought a formal meta-analysis inappropriate owing to the heterogeneity of the interventions, settings, participants, and outcome measures. Instead we used a rating system of levels of evidence to draw conclusions on effectiveness, based on previously used best evidence syntheses. ${ }^{1631}$ We defined five levels on the basis of study design, methodological quality, and sample size: strong, moderate, limited, inconclusive, or no evidence for effect (see www.mrc-epid. cam.ac.uk/Publications/Supplementary_Material/ VanSluijsBMJ2007/), and conclusions were drawn on the basis of the consistency of results of studies with the highest available level of quality. If at least two thirds $(66.6 \%)$ of the relevant studies were reported to have significant results in the same direction then we considered the overall results to be consistent. In a stratified analysis we assessed levels of evidence for studies according to setting, target population, and type of intervention (educational only, environmental or policy based only, or a combination of both, "multicomponent").

\section{RESULTS}

Overall, 3045 references were retrieved from the database search (PubMed, n=2000; Psychinfo, $\mathrm{n}=340$; Scopus, $\mathrm{n}=692$; Ovid Medline, $\mathrm{n}=591$; Sportdiscus, $n=472$; Embase, $n=400)$. Fifty one studies met the inclusion criteria, a further six were added after searching the citations (figure). Thirty three included children $^{\text {w1-w47 }}$ and 24 included adolescents. ${ }^{\text {w48-w77 }}$ Tables 2 and 3 show the characteristics of the studies.

\section{Methodological quality}

Agreement was $85.9 \%$ on the 570 items scored during the quality assessment $(\kappa=0.72$, substantial agreement); full consensus was reached after discussion. Overall 24 studies (42\%) exhibited high methodological quality, of which $15(25 \%)$ had more than 250 participants (see www.mrc-epid.cam.ac.uk/Publica tions/Supplementary_Material/VanSluijsBMJ2007/ ). Most studies applied intention to treat analyses and measured all study groups at similar times, but only 10 studies $(18 \%)$ had a follow-up of six months or longer. Insufficient information was provided to score the adequacy of the randomisation procedure for 34 studies $(60 \%)$, and 33 studies $(58 \%)$ lacked information on allocation concealment at outcome assessment.

\section{Study characteristics}

Eighteen of the 33 studies in children were carried out in the United States, seven in the United Kingdom, and the remainder in other countries. Most of the child studies (82\%) evaluated school based interventions, 14 of which included a community or family component. Around half of the child interventions were educational whereas a third used a multicomponent approach. Just over half of the studies relied on child reported or parent reported questionnaires or diaries as the main measure of physical activity (see www.mrc-epid.cam.ac.uk/Publications/Supplemen tary_Material/VanSluijsBMJ2007/). Twelve studies used an objective measure of physical activity whereas three used observation methods. Only five of these assessed overall physical activity; the remainder mostly assessed activity during physical education or playtime. Nineteen of the studies assessed overall physical activity, eight measured school based physical activity only, and six assessed out of school physical activity.

Eighteen of the 24 studies in adolescents were carried out in the United States and six in other countries. Almost all evaluated school based interventions, six of which included involvement of the family or community. Five studies included a follow-up measurement of six months or more (see www.mrc-epid. cam.ac.uk/Publications/Supplementary_Material/ VanSluijsBMJ2007/). Measurement of physical activity was mostly focused on non-school related activities and carried out with self reported questionnaire or recall instruments. Four studies used an objective measure as the main measure of physical activity, all assessing total physical activity, and one study used direct observation to assess physical education related physical activity.

\section{Evidence of effect on physical activity}

Thirty eight studies reported a positive intervention effect $(67 \%)$, achieving statistical significance in 27 $(47 \%)$. This included 14 studies in children $(42 \%)$ and 13 in adolescents (54\%). Significant results ranged from an increase of 2.6 minutes during physical education classes to a $42 \%$ increase in participation in regular physical activity and an increase of 83 minutes per week in moderate to vigorous physical activity.

Table 4 summarises the stratified levels of evidence for the effectiveness of interventions to promote physical activity in children and adolescents.

\section{Intervention types in children}

Nineteen studies evaluated education only interventions, including one large high quality randomised controlled trial, ${ }^{\text {w11 }}$ two large high quality controlled trials, ${ }^{\mathrm{w} 3 \mathrm{w} 4}$ four small high quality randomised controlled trials, ${ }^{\text {w15-w17 }}{ }^{\text {w23 }}$ and seven low quality randomised controlled trials. ${ }^{\mathrm{w} 1 \mathrm{w} 2 \mathrm{w} 8 \mathrm{w} 10 \mathrm{w} 19-\mathrm{w} 21}$ Four of these reported a statistically significant intervention effect, therefore no overall evidence of an effect of education only interventions was identified. Four studies evaluated changes in the school 
Table 3 | Intervention characteristics of included studies aimed at increasing physical activity in adolescents (named reference is main reference)

Study design*;
country $\quad$ Setting $\quad \begin{gathered}\text { Target } \\ \text { population }\end{gathered}$ Participants

Educational interventions:

Jago $2006^{\text {w48 }}$ (Fit Randomised Community One sex

for life) $\quad$ controlled trial

(boy scout troop);

USA

$\begin{array}{llll}\begin{array}{l}\text { Patrick 2006 } \\ \text { (PACE }+ \text { for }\end{array} & \text { Randomised } & \text { Primary care } & \text { None } \\ \text { controlled trial } & & \end{array}$

(PACE+

adolescents) (individual); USA $\mathrm{n}=473$; mean age Intervention group: 9 weeks' duration: troop meetings (once weekly) and internet 13 (SD 0.1 years); intervention (asked to log on twice weekly) aimed at increasing physical activity males only; $16 \quad$ skills, physical activity self efficacy, and goal setting. Troop meetings included troops started in 20 minute activity sessions. Internet based programme focused on role modelling, spring, 26 in autumn goal setting, goal review, and problem solving. Badge could be earned, with points for goal setting and achievement, and attending troop meeting. Control group: fruit and vegetable intervention, as above

$\mathrm{n}=819$; mean age Intervention group: 12 month programme, one stage based computer tailored

12.7 (SD 1.3)

years; $46.5 \%$

males intervention with endorsement of primary care provider. Focus on diet and physical activity (MVPA and sedentary behaviour). After initial consultation, participants received manual and 11 telephone based follow-up sessions. Parents were targeted to help them encourage attempts at behaviour change. Control group: sun protection intervention, as above

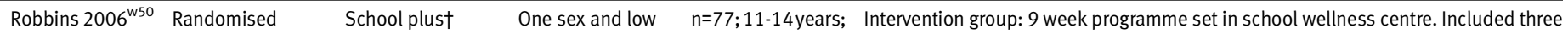
(Girls on the controlled trial SES

move) (grade); USA

SES females only; individually tailored computer sessions with face to face feedback from schoo sedentary (ready paediatric nurse, and two telephone calls with research assistant, focusing on to change physical agreed goals. Parents were posted tip sheets to support girls to achieve goals. activity behaviour) Control group: one page leaflet with age specific recommendations for physical activity

\begin{tabular}{|c|c|c|c|c|}
\hline Frenn $2005^{\mathrm{w} 51}$ & $\begin{array}{l}\text { Controlled trial } \\
\text { (class); USA }\end{array}$ & School only & None & $\begin{array}{l}n=132 ; 12 \text { and } \\
13 \text { years; both } \\
\text { sexes } \$\end{array}$ \\
\hline $\begin{array}{l}\text { Schofield } \\
2005^{\text {w52 }}\end{array}$ & $\begin{array}{l}\text { Controlled trial } \\
\text { (school); Australia }\end{array}$ & School only & One sex & $\begin{array}{l}\mathrm{n}=68 ; \text { mean age } \\
15.8 \text { (SD 0.8) } \\
\text { years; females } \\
\text { only; inactive }\end{array}$ \\
\hline $\begin{array}{l}\text { Tsorbatzoudis } \\
2005^{\text {w53 }}\end{array}$ & $\begin{array}{l}\text { Controlled trial } \\
\text { (school); Greece }\end{array}$ & School only & None & $\begin{array}{l}n=366 ; \text { mean age } \\
14.2(S D 0.7) \\
\text { years; } 52 \% \\
\text { females }\end{array}$ \\
\hline
\end{tabular}

Intervention group: eight session blackboard based intervention (internet) in science classes (40 minutes per class). Individually tailored feedback on basis of stage of change to increase physical activity and improve diet. Control group: usual curriculum

Intervention group 1: twelve weekly sessions, with pedometer based self-monitoring and educative meetings encouraging daily increases in steps until $10000 /$ day. Intervention group 2: twelve weekly sessions, with self monitoring by recording daily minutes of MVPA and educative meetings encouraging daily activity by 10-15 minutes per week until 30-60 minutes per day. Control group: no intervention Intervention group: 12 week educational programme, three sessions per week. Aim to support cognitive, emotional, and behavioural components of student's attitude to physical activity to change behaviour. In addition, three 45 minutes lectures given on effective behaviour change, goal setting, and health and exercise. Weekly poster on announcement board. Control group: usual curriculum

Wilson $2005^{\text {w54 }}$ Controlled trial School only Low SES (school); USA

$\mathrm{n}=48$; mean age

11.0 (SD 0.6)

years; $71 \%$

Intervention group: after school programme with three 2 hour meetings per week during 4 weeks. Programme emphasised increasing intrinsic motivation and behaviour skills to increase MVPA to 60 minutes per day. Each session included a one hour activity component chosen by the students. Control group: after school programme providing information on general health

\begin{tabular}{|c|c|c|c|c|c|}
\hline $\begin{array}{l}\text { Bayne-Smith } \\
2004^{\text {w55 }} \text { (PATH) }\end{array}$ & $\begin{array}{l}\text { Randomised } \\
\text { controlled trial } \\
\text { (individual and } \\
\text { class); USA }\end{array}$ & School only & One sex & $\begin{array}{l}\mathrm{n}=442 ; \text { mean age } \\
16.0 \text { (SD } 1.3) \\
\text { years; females } \\
\text { only }\end{array}$ & $\begin{array}{l}\text { Intervention group: } 12 \text { week, physical education curriculum based programme. Daily } \\
30 \text { minute classes (five days per week); classes consisted of 5-10 minute lecture and } \\
20-25 \text { minutes of vigorous physical activity, with additional homework assignments. } \\
\text { Control group: normal curriculum (no lecture, so about } 5 \text { minutes more physical } \\
\text { activity per class) }\end{array}$ \\
\hline Hsu $2004^{\text {w56 }}$ & $\begin{array}{l}\text { Randomised } \\
\text { controlled trial } \\
\text { (class); Taiwan }\end{array}$ & School only & One sex & $\begin{array}{l}\mathrm{n}=188 ; \text { mean age } \\
16.45 \text { (SE 0.31) } \\
\text { years; females } \\
\text { only }\end{array}$ & $\begin{array}{l}\text { Intervention group: } 12 \text { week intervention. Usual physical education plus education } \\
\text { based programme focusing on physical activity knowledge, self efficacy, and } \\
\text { attitudes. One } 50 \text { minute seminar held then regular discussions in small groups (10 } \\
\text { or } 11 \text { ), led by peer leaders, to encourage and support physical activity. Control } \\
\text { group: usual curriculum }\end{array}$ \\
\hline $\begin{array}{l}\text { Ortega-Sanchez } \\
2004^{\text {w57 }}\end{array}$ & $\begin{array}{l}\text { Randomised } \\
\text { controlled trial } \\
\text { (individual); Spain }\end{array}$ & Primary care & None & $\begin{array}{l}\mathrm{n}=448 ; \text { mean age } \\
17.0 \text { (SD } 2.4) \\
\text { years, } 58 \% \text { males }\end{array}$ & $\begin{array}{l}\text { Intervention group: two 5-10 minutes of counselling by doctor (baseline and } \\
6 \text { months) on basis of current activity level (either initiation, increase, reinforcement } \\
\text { counselling). Based on ask-assess-advice principle. Control group: no advice }\end{array}$ \\
\hline $\begin{array}{l}\text { Prochaska } \\
2004^{\mathrm{w} 58}\end{array}$ & $\begin{array}{l}\text { Randomised } \\
\text { controlled trial } \\
\text { (class); USA }\end{array}$ & School only & None & $\begin{array}{l}\mathrm{n}=138 ; \text { mean age } \\
12.1(\mathrm{SD} 0.9) \\
\text { years; } 65 \% \\
\text { females }\end{array}$ & $\begin{array}{l}\text { Intervention group 1: } 30 \text { minute computer based health education session, stages of } \\
\text { change based health assessment with tailored feedback with individual plans for } \\
\text { behaviour change or relapse prevention. Intervention group 2: same as above, } \\
\text { including nutrition intervention. Control group: no intervention }\end{array}$ \\
\hline Frenn $2003^{\text {w59 }}$ & $\begin{array}{l}\text { Controlled trial } \\
\text { (class); USA }\end{array}$ & School only & None & $\begin{array}{l}\mathrm{n}=178 ; \text { age } \\
12-15 \text { years; both } \\
\text { sexes } \ddagger\end{array}$ & $\begin{array}{l}\text { Intervention group: four internet or video delivered health education sessions (stage } \\
\text { of change based), setting up of gym lab run by active students (duration one month). } \\
\text { Control group: usual curriculum }\end{array}$ \\
\hline $\begin{array}{l}\text { Gortmaker } \\
1999^{\text {w60 }} \text { (Planet } \\
\text { Health) }\end{array}$ & $\begin{array}{l}\text { Randomised } \\
\text { controlled trial } \\
\text { (school); USA }\end{array}$ & School only & None & $\begin{array}{l}\mathrm{n}=1560 ; \text { age } 11 \\
\text { and } 12 \text { years; both } \\
\text { sexes } \neq\end{array}$ & $\begin{array}{l}\text { Intervention group: } 2 \text { year programme, } 32 \text { classroom based sessions taught by } \\
\text { regular teachers. Interdisciplinary intervention for prevention of obesity aimed at } \\
\text { decreasing television viewing, making space for activity, with focus on "lifestyle" } \\
\text { changes in behaviour. Control group: usual curriculum }\end{array}$ \\
\hline $\begin{array}{l}\text { Perry } \\
1994^{\text {w61 w62 }} \\
\text { (Class of 1989) }\end{array}$ & $\begin{array}{l}\text { Controlled trial } \\
\text { (class), (3rd year of } \\
7 \text { year community } \\
\text { intervention); USA }\end{array}$ & School plust & None & $\begin{array}{l}\mathrm{n}=2406 ; \text { age } 13 \\
\text { and } 14 \text { years } \S \\
\text { both sexes } \neq\end{array}$ & $\begin{array}{l}\text { Intervention group: classroom based intervention using peer leaders; self } \\
\text { monitoring intervention FM } 250 \text { in year } 8 \text { (hypothetically cycle } 250 \text { miles between } \\
\text { two towns in } 4 \text { weeks, based on daily energy expenditure). Control group: no } \\
\text { intervention }\end{array}$ \\
\hline
\end{tabular}


$\begin{array}{llll}\text { Nader } 1992^{\text {w63 }} & \begin{array}{l}\text { Randomised } \\ \text { controlled trial }\end{array} & \text { Family } & \text { Non }\end{array}$ (school); USA

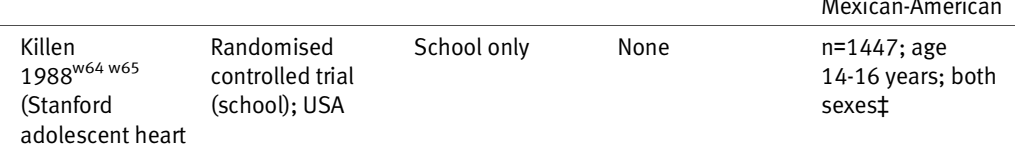

adolescent heart

health

programme)

Perry $1987^{\text {w66 }}$

(Slice of life)

Randomised School only None

controlled trial

(school); USA $\mathrm{n}=323$; mean age

12 years, both

sexesł; $59 \%$

Mexican-American included aerobic exercise, education (separate for children and adults), behaviour management, and heart healthy snacks (duration 3 months); also six maintenance sessions over following 9 months. Control group: no intervention

Intervention group: 7 week classroom based educational programme (three 50 minute sessions per week) taught by special teachers in five modules (physical education, diet, smoking, stress, problem solving). Each module contained health benefits, skills acquisition, resisting social influence, and skills practice. Control group: usual curriculum

n=280; age 14 and Intervention group: 10 sessions of peer led classroom based educational 15 years; both sexesł intervention with focus on changing environmental, personality, and behavioura
Environmental interventions:

\begin{tabular}{|c|c|c|c|}
\hline $\begin{array}{l}\text { Sallis } \\
2003^{\text {w67 w68 }}(M- \\
\text { SPAN) }\end{array}$ & $\begin{array}{l}\text { Randomised } \\
\text { controlled trial } \\
\text { (school); USA }\end{array}$ & School only & None \\
\hline
\end{tabular}

$n=24$ schools (mean 1109 per school); age 11-13 years; both sexesł attributes to behaviour change (including videotaped instructions and goal setting, self monitoring, social support, and how to change environment). Control group: usual curriculum

Intervention group: 2 year programme based on ecological model focused on physical activity and nutrition. Physical activity intervention included changing content and structure of physical education, increasing choice for physical activity during leisure periods and environmental changes (increased supervision, equipment, and activities). No health promotion. Control group: usual curriculum (schools received $\$ 1000$ ( $£ 500 ; € 700$ ) for physical education equipment)

Multicomponent interventions:

Young $2006^{\text {w69 }}$

$\begin{array}{ll}\text { Young } 2006^{\text {w69 }} & \begin{array}{l}\text { Randomised } \\ \text { controlled tria }\end{array}\end{array}$

(individual); USA

School plust $\quad$ One sex

$\mathrm{n}=221$; mean age

13.8 (SD 0.5)

years; females only

Intervention group: one school year programme focusing on social independence, environmental factors, and problem solving skills. Delivery during class lectures, small group discussions, and homework activities. Included physical activity monitoring and strategies to maximise physical activity during physical education classes. Families were invited for workshop and received newsletters and parentchild homework. Control group: usual curriculum

\begin{tabular}{|c|c|c|c|c|}
\hline $\begin{array}{l}\text { Haerens } \\
2005^{\text {w70 w71 }}\end{array}$ & $\begin{array}{l}\text { Randomised } \\
\text { controlled trial } \\
\text { (school); Belgium }\end{array}$ & School plust & None & $\begin{array}{l}n=2840 ; \text { mean age } \\
13 \text { (SD 0.8) years; } \\
36.6 \% \text { females }\end{array}$ \\
\hline
\end{tabular}

Intervention group 1: 2 year intervention implemented by school staff. Focus on creating opportunities for physical activity during breaks, lunch, and after school. Provision of extra sports material and setting up of variety of (non-competitive) activities. Computer tailored intervention (once in year 2 ) providing feedback on physical activity levels and determinants. Intervention group 2: intervention group 1 plus parents invited to interactive meeting on physical activity, diet, and health. Parents received $C D$ with similar computer tailored intervention and regular newsletters. Control group: usual curriculum

$\begin{array}{llll}\begin{array}{l}\text { Pate } 2005^{\text {w72-w74 }} \\ \text { (LEAP) }\end{array} & \text { Randomised } & \text { School plust } & \text { One sex } \\ & \begin{array}{l}\text { controlled trial } \\ \text { (school); USA }\end{array} & \end{array}$

$\mathrm{n}=2744$, mean age

13.6 (SD 0.6) years; females only

cumponent intervention with emphasis on enhancing physical activity self efficacy through successful experiences of physical activities and skill development. Focus on six components: changing physical education, providing health education, creating supportive school environment, school health services, staff health promotion, and family based and community based activities. Control group: regular physical education classes

\begin{tabular}{|c|c|c|c|c|c|}
\hline $\begin{array}{l}\text { Jamner 2004 } \\
\text { (Project FAB) }\end{array}$ & $\begin{array}{l}\text { Controlled trial } \\
\text { (school); USA }\end{array}$ & School only & One sex & $\begin{array}{l}\mathrm{n}=58 \text {; age } \\
14-16 \text { years; } \\
\text { females only } \\
\text { (sedentary and } \\
\leq 75 \text { centile for } \\
\text { fitness) }\end{array}$ & $\begin{array}{l}\text { Intervention group: } 4 \text { months' intervention. Additional classes (five } 60 \text { minutes per } \\
\text { week), four activity based classes with female targeted activities, one discussion } \\
\text { class on health benefits from physical activity and strategies to increase physical } \\
\text { activity. Control group: usual curriculum }\end{array}$ \\
\hline Simon $2004^{w 76}$ & $\begin{array}{l}\text { Randomised } \\
\text { controlled trial } \\
\text { (school); France }\end{array}$ & School plust & None & $\begin{array}{l}\mathrm{n}=954 ; \text { mean age } \\
11.6 \text { (SD 0.7) } \\
\text { years; intervention } \\
\text { group, } 46.3 \% \\
\text { males: control } \\
\text { group, } 51.8 \% \\
\text { males }\end{array}$ & $\begin{array}{l}\text { Intervention group: } 4 \text { years' duration, in partnership with families and community } \\
\text { groups. Focus on three areas: increasing knowledge, attitudes, beliefs, and } \\
\text { motivation for physical activity through debates and providing information; social } \\
\text { support form parents, peers, teachers, and physical activity instructors; and } \\
\text { changing environmental conditions for physical activity. Educational component } \\
\text { and new opportunities for physical activity. Control group: usual health curriculum } \\
\text { and physical education }\end{array}$ \\
\hline $\begin{array}{l}\text { Neumark- } \\
\text { Sztainer } 2003^{\text {w77 }} \\
\text { (New moves) }\end{array}$ & $\begin{array}{l}\text { Randomised } \\
\text { controlled trial } \\
\text { (school); USA }\end{array}$ & School only & One sex & $\begin{array}{l}\mathrm{n}=201 ; \text { mean age } \\
15.4 \text { (SD 1.1) } \\
\text { years; females } \\
\text { only; low activity }\end{array}$ & $\begin{array}{l}\text { Intervention group: } 16 \text { week programme, five classes per week. Females only } \\
\text { additional physical education classes four times weekly and one educational } \\
\text { session per week (either discussing social support or nutrition). Aimed to create } \\
\text { environment in which larger girls could feel comfortable being physically active. } \\
\text { Control group: usual curriculum }\end{array}$ \\
\hline
\end{tabular}

SES=socioeconomic status; $M V P A=$ moderate-vigorous or vigorous physical activity.

*Level of randomisation or group allocation given in brackets.

tincludes involvement of family or community.

$\ddagger$ No further descriptive data available on baseline sample. 
Table 4 | Summary of levels of evidence for effect of interventions to promote physical activity in children and in adolescents, stratified by setting, characteristics of intervention, and target group

\begin{tabular}{|c|c|c|c|c|}
\hline \multirow[b]{2}{*}{ Variables } & \multicolumn{2}{|c|}{ Children (33 studies) } & \multicolumn{2}{|c|}{ Adolescents (24 studies) } \\
\hline & No of studies & Level of evidence & No of studies & Level of evidence \\
\hline \multicolumn{5}{|l|}{ Intervention type: } \\
\hline Educational & 19 & No & 17 & No \\
\hline Environmental or policy & 4 & Limited & 1 & Inconclusive \\
\hline Multicomponent & 10 & Inconclusive & 6 & Strong \\
\hline \multicolumn{5}{|l|}{ Setting: } \\
\hline School & 13 & Inconclusive & 14 & Inconclusive \\
\hline School plus community or family & 14 & Inconclusive & 6 & Strong \\
\hline Family & 4 & No & 1 & Inconclusive \\
\hline Community & 2 & No & 1 & Inconclusive \\
\hline Primary care & 0 & No & 2 & Inconclusive \\
\hline \multicolumn{5}{|l|}{ Target group: } \\
\hline One sex only & 5 & No & 9 & Inconclusive \\
\hline Ethnic minority populations & 10 & No & 0 & No \\
\hline Low SES populations & 3 & Limited & 2 & Inconclusive \\
\hline
\end{tabular}

Categories are exclusive for setting and intervention type but not for target group. SES=socioeconomic status.

environment, including two low quality randomised controlled trials. ${ }^{\text {w24 }}{ }^{26}$ Both of these reported a significant intervention effect, providing limited evidence of an effect of environmental interventions.

Ten studies evaluated multicomponent interventions in children, including three large high qual-

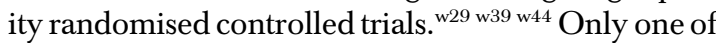
these high quality trials reported a significant positive effect, equating to inconclusive evidence of effectiveness.

\section{Intervention types in adolescents}

Seventeen studies evaluated education only interventions in adolescents, including four large high

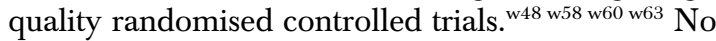
evidence of an effect was found, with only one of the large high quality trials reporting statistically significant positive results. Only one study, a low quality randomised controlled trial, ${ }^{\text {w67 }}$ evaluated the effect of an environmental intervention, providing inconclusive evidence of an effect.

Six studies evaluated multicomponent interventions, all in the school setting. Three were large high quality randomised controlled trials, ${ }^{\text {w69 w72 w76 }}$ which all showed significant positive results, providing strong evidence of an effect of multicomponent interventions.

\section{Settings in studies of children}

Twenty seven studies evaluated school based interventions. Thirteen of these were restricted to the school setting only, including five randomised controlled trials, one of high quality ${ }^{\text {w3 }}$ and four of lower quality. ${ }^{\mathrm{w} 8 \mathrm{w} 21 \mathrm{w} 24 \mathrm{w} 26}$ Three of these randomised controlled trials reported significant positive intervention effects, resulting in the classification of inconclusive evidence of an effect of school only interventions. The other 14 school based interventions also included family or community components, such as homework assignments to do with parents or incorporation of physical activity into existing community events. Two large high quality randomised controlled trials were identified, ${ }^{\text {w29 }}{ }^{44}$ one of which showed a significant positive intervention effect, suggesting inconclusive evidence of an effect.

Four studies evaluated family based interventions, including three small high quality randomised controlled trials. ${ }^{\text {w16 w17 w23 }}$ Only one reported a significant effect, which favoured the control group. One large high quality randomised controlled trial ${ }^{\mathrm{w} 11}$ and one small high quality randomised controlled trial ${ }^{\mathrm{w} 15}$ evaluated the effect of a community based intervention, and neither reported a positive intervention effect. This review therefore provides no evidence of an effect of either family based or community based interventions among children.

\section{Settings in studies of adolescents}

Of the 20 studies that evaluated school based interventions, 14 were restricted to the school setting, including two large high quality randomised controlled trials, ${ }^{\text {w5 }}{ }^{60}$ one of which reported a statistically significant intervention effect. $^{\text {w58 }}$ This represents inconclusive evidence of an effect. Six studies evaluated school based interventions also including family or community involvement, three of which were large high quality randomised controlled trials. ${ }^{\text {w69 w72 w76 }}$ Two of these large high quality trials showed statistically significant positive results suggesting strong evidence of an effect of school based interventions including family or community involvement.

The only study evaluating a family based intervention, a high quality randomised controlled trial, ${ }^{\text {w63 }}$ did not report a positive effect, as did the high quality randomised controlled trial ${ }^{\mathrm{w} 48}$ evaluating a community based intervention. One of the two low quality randomised controlled trials evaluating 


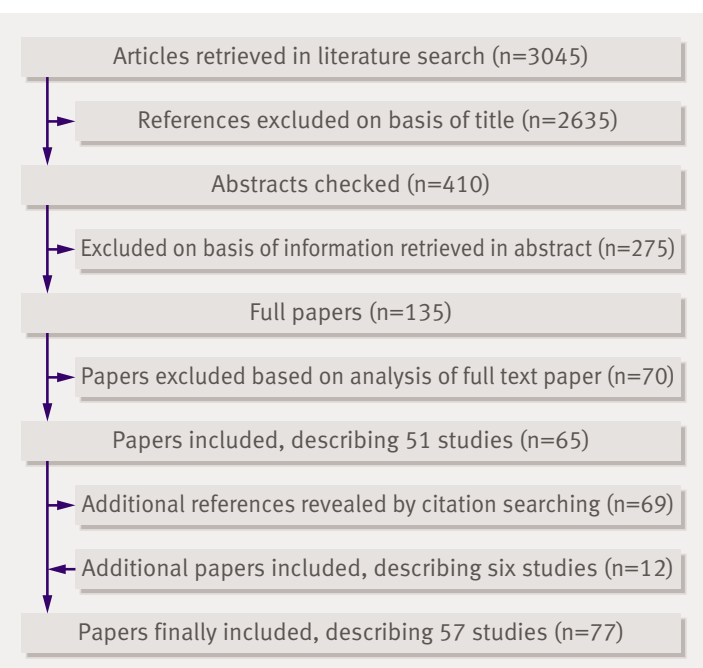

Identification of included studies

primary care based interventions $\mathrm{w}^{\mathrm{w} 4 \mathrm{w} 57}$ showed a significant positive effect. Consequently evidence of an effect of either family based, community based, or primary care based interventions in adolescents is inconclusive.

\section{Target populations in children}

Five studies evaluated interventions targeted specifically at girls: one large high quality randomised controlled trial, ${ }^{\text {w11 }}$ two small high quality randomised controlled trials, ${ }^{\mathrm{w} 15}{ }^{\mathrm{w} 16}$ and two low quality randomised controlled trials. ${ }^{\text {w8 w19 }}$ Four reported positive effects but only one was significant. Ten studies evaluated interventions specifically aimed at ethnic minority groups, including four small high quality randomised controlled trials ${ }^{\mathrm{w15-w17} w 23}$ and four low quality randomised controlled trials. ${ }^{\mathrm{w} 2 \mathrm{w} 10 \mathrm{w} 19 \mathrm{w} 33}$ Only one low quality randomised controlled trial reported a significant positive effect. Therefore no overall evidence of an effect for interventions targeting girls or ethnic minority groups was found. Three controlled trials, including two of high quality, ${ }^{\text {w3 w28 }}$ assessed the effect of interventions targeting children from low socioeconomic backgrounds. All reported a significant positive effect, resulting in a classification of limited evidence of an effect for these interventions.

\section{Target populations in adolescents}

Eight studies evaluated interventions specifically aimed at adolescent girls and one aimed at boys. Three were large high quality randomised controlled trials, ${ }^{\mathrm{w} 48 \text { w69 w72 }}$ of which one showed significant positive results. In two small high quality studies - one randomised controlled trial ${ }^{\mathrm{w} 50}$ and one controlled trial ${ }^{\mathrm{w} 54}$-interventions were aimed at low socioeconomic groups, with only one reporting a significant intervention effect. Consequently evidence of an effect of interventions targeting adolescents of one sex or from low socioeconomic groups is inconclusive.

\section{DISCUSSION}

We found that in children there is limited evidence of an effect of interventions targeting low socioeconomic populations and environmental interventions and the evidence of an effect for multicomponent interventions and the two types of school based interventions is inconclusive. More adequately powered high quality research is needed to strengthen and confirm these results. In general, interventions achieved important changes, such as a $13 \%$ increase in play time spent in moderate to vigorous physical activity. No evidence of effectiveness was observed in six of the intervention categories. This review especially raises questions about the usefulness of targeting interventions at children from ethnic minority populations or carrying out family based or community based interventions, as most of the studies identified did not report positive results. Before pursuing these strategies further, it is necessary to identify and learn from the limitations of these interventions and their evaluations. In addition, no evidence of an effect was found for educational interventions and the interventions targeting females, despite more than $67 \%$ of studies evaluating these interventions reporting positive effects. Most of these were low quality studies and did not always achieve statistical significance.

Overall there was more evidence for an effect of interventions among adolescents than among children. However, more studies in adolescents compared with studies in children were of high quality and included a large sample size $(33 \% v 21 \%)$. Adolescents are also known to be less active than children $^{3334}$ so may exhibit greater potential for change. Effects ranged from increases of three minutes during physical education to a $50 \%$ increase in the number of participants being regularly active. Strong evidence was found for the effectiveness of school based interventions including family or community involvement and multicomponent interventions. No evidence of an effect was observed for educational interventions although an overall positive trend was observed. This trend is, however, mainly due to the results of studies with lower methodological quality and should therefore be interpreted with caution. This review also shows inconclusive evidence of an effect in adolescents in other categories, warranting further investigation.

\section{Intervention approaches}

Almost a third of the included studies in children were targeted at minority ethnic groups, although the evidence on the association between ethnicity and physical activity in children is fairly inconsistent. ${ }^{356}$ In contrast an association has often been reported in adolescents, with levels of physical activity tending to be lower in non-white ethnic groups, ${ }^{3537-39}$ yet no interventions targeting adolescents from minority ethnic groups were identified. Low socioeconomic status has been identified as a possible determinant of physical inactivity. ${ }^{40-43}$ Recently, trials of interventions targeting socially disadvantaged people 
provided some evidence of the potential of this strategy. A higher level of activity in males compared with females is consistently observed throughout childhood and adolescence and evidence also suggests that both sexes tend to become less active with increasing age. ${ }^{3355}$ This review raises doubts about whether targeting females and males separately is an effective approach, although a positive trend was observed among children. Most of the studies investigating differential response by sex did not find one, casting more doubt on the need for separate approaches for the sexes.

Parental factors and the home environment are believed to influence physical activity, ${ }^{445}$ yet few interventions were specifically aimed at the home and those that have been carried out did not show significant positive results. An increasing number of school based interventions do, however, include some parental involvement, although usually limited to newsletters and homework assignments. Evidence of effectiveness of these interventions in adolescents was strong, although in children the evidence is still inconclusive. Whether the strategy of involving parents in interventions will be as effective for children should be the focus of future research.

The conclusion of strong evidence of effect of multicomponent interventions in adolescents and the limited evidence of effect of environmental interventions in children is in keeping with the ecological approach to behaviour change as advocated in recent years. ${ }^{46-49}$ The environmental or policy element of multicomponent interventions mostly consisted of alterations to the physical education programme, such as additional classes, physical education teacher training, or the availability of additional equipment. Observations of physical activity during physical education classes mostly showed some increases, but few effects were observed in overall physical activity. This raises the question of whether children might compensate during the rest of the day. It is therefore important to use objective measures to assess the overall effect of the intervention on total activity levels.

Young children's activity is typically intermittent ${ }^{34}$ in contrast to that of adolescents, which is more structured and planned. Although traditional cognitive approaches, potentially combined with environmental approaches, may increase activity among adolescents and older children ( $\geq 10$ years), more structural environmental or policy changes might be needed to change younger children's physical activity behaviour. ${ }^{50}$ This is supported by the evidence of an effect of environmental interventions, which tended to be evaluated in children in the lower grades (grades 1-4) at primary school. Few studies, however, included preschool aged children.

Implementation of interventions

Factors that may have limited effectiveness are the levels of exposure to the intervention and adherence. Several papers reported problems in these areas. For example, Pate et al $^{\mathrm{w} 37}$ described that only $5 \%$ of participants attended at least half of the sessions offered. Most papers, however, did not describe attendance, implementation, or quality assurance of the intervention, making it impossible to assess the impact these factors may have had on the overall findings.

Most of the studies included in this review were carried out in the United States, raising questions about the generalisability of these results to other countries. Feasibility and effectiveness of cross national implementation is potentially limited owing to known differences in infrastructure, school systems, environments, and social norms. To assess the usefulness of these strategies across different cultures we would advocate replicating evaluations of previously successful interventions adapted to a specific country.

\section{Methodological quality}

Various limitations in study design and subsequent reporting were identified. In particular, information was lacking on the randomisation procedure and blinding at outcome assessment, limiting the interpretation of the methodological quality. Brief descriptions of interventions hampered stratification of the studies and analyses of potential effective components. Overall, methodological limitations across the studies included short duration of follow-up, inadequate adjustment for potential confounders, and a lack of adjustment for clustering when randomisation was carried out at group level. Another limitation was the lack of precision of the physical activity outcome measures. Eighteen of the studies in children used self reported or parent reported measures (55\%), just over half of which were not reported to be previously validated, possibly limiting responsiveness. Studies using observation or objective measures of physical activity were in fact more likely to report significant positive results than studies with a self reported measure, both in children and in adolescents.

\section{Conclusion}

Various policy documents have called for the development of effective strategies to increase physical activity in children and adolescents to help halt or reverse the increase in obesity and to improve other aspects of health. ${ }^{4115152}$ Based on the published evidence to date it seems that a multilevel approach to promoting physical activity, combining school based interventions with family or community involvement and educational interventions with policy and environmental changes, is likely to be effective among adolescents and should be promoted. For children, there is limited evidence of an effect for environmental interventions and interventions targeting those from low socioeconomic groups. Research should focus on filling the gaps identified in this review, such as the lack of studies among adolescent ethnic minority populations and preschool children, and of interventions outside the school setting. Furthermore, 


\section{WHAT IS ALREADY KNOWN ON THIS TOPIC}

Children and adolescents are believed to have low levels of physical activity, which is

associated with obesity and other health problems

It is unclear what strategies might be effective to promote physical activity

\section{WHAT THIS STUDY ADDS}

Multicomponent interventions and interventions including school and family or community involvement may make important differences in physical activity levels in adolescents For children some evidence of effect was shown for environmental interventions and those targeted at children from low socioeconomic backgrounds

future studies should aim to strengthen the evidence with rigorous design, appropriate sample size, followup beyond post intervention to assess maintenance, use of objective measures of overall activity, and assessment of factors along the causal pathway. ${ }^{534}$ Moreover, studies should include assessment of implementation issues and carry out cost effectiveness analyses to further inform future public health strategies in this topic.

We thank Stephen Sharp for his help in interpreting the statistical methods applied and results presented in the included papers.

Contributors: EMFvS led the review, identified the research question, and designed the search strategy. She is guarantor for the paper. EMFvS and AMMcM carried out the literature searches and screened the initial results, assessed methodological quality, extracted data, analysed the findings, and drafted the tables. EMFvS drafted the manuscript. All authors contributed to synthesising the results and critical revision of the manuscript, and all approved the final version.

Funding: This work was supported by programme grant funding from the Medical Research Council.

Competing interests: None declared.

Ethical approval: Not required.

1 Zaninotto P, Wardle H, Stamatakis E, Mindell J, Head J. Forecasting obesity to 2010. London: Department of Health, 2006.

2 Wareham N, van Sluijs E, Ekelund U. Physical activity and obesity prevention: a review of the current evidence. Proc Nutr Soc 2005;64:229-47.

3 Promoting better health for young people through physical activity and sport. Washington, DC: US Secretary of Health and Human Services and US Secretary of Education, 2006.

4 Department of Health. Choosing activity: a physical activity action plan. London: DoH, 2005.

5 Lobstein T, Baur L, Uauy R. Obesity in children and young people: a crisis in public health. Obes Rev 2004;5(suppl 1):4-85

6 Andersen LB, Harro M, Sardinha LB, Froberg K, Ekelund U, Brage S, et al. Physical activity and clustered cardiovascular risk in children: a cross-sectional study (the European youth heart study). Lancet 2006;368:299-304.

7 Dollman J, Norton K, Norton L. Evidence for secular trends in children's physical activity behaviour. Br J Sports Med 2005;39:892-7.

8 Sleap M, Warburton P. Physical activity levels of 5-11-year-old children in England: cumulative evidence from three direct observation studies. Int J Sports Med 1996;17:248-56.

9 Telama R, Yang X, Viikari J, Välimäki I, Wanne O, Raitakari O. Physical activity from childhood to adulthood: a 21-year tracking study. Am J Prev Med 2005;28:267-73.

10 Twisk JW, Kemper HC, van Mechelen W. Tracking of activity and fitness and the relationship with cardiovascular disease risk factors. Med Sci Sports Exerc 2000;32:1455-61.

11 World Health Organization. Global strategy on diet, physical activity and health. Geneva: WHO, 2004.

12 Doak CM, Visscher TLS, Renders CM, Seidell JC. The prevention of overweight and obesity in children and adolescents: a review of interventions and programmes. Obes Rev 2006;7:111-36.

13 Campbell K, Waters E, O'Meara S, Summerbell C. Interventions for preventing obesity in children. Cochrane Database Syst Rev 2001 (1):CD001871.
14 Dietz WH, Gortmaker SL. Preventing obesity in children and adolescents. Annu Rev Public Health 2001;22:337-53.

15 Hillsdon M, Foster C, Thorogood M. Interventions for promoting physical activity. Cochrane Database Syst Rev 2005;(1):CD003180.

16 Van Sluijs EM, van Poppel MN, van Mechelen W. Stage-based lifestyle interventions in primary care: are they effective? Am J Prev Med 2004;26:330-43.

17 Smith BJ. Promotion of physical activity in primary health care: update of the evidence on interventions. J Sci Med Sport 2004;7(suppl 1):67-73.

18 Timperio A, Salmon J, Ball K. Evidence-based strategies to promote physical activity among children, adolescents and young adults: review and update. J Sci Med Sport 2004;7(suppl 1):20-9.

19 Jago R, Baranowski T. Non-curricular approaches for increasing physical activity in youth: a review. Prev Med 2004;39:157-63.

20 Salmon J, King AC. Population approaches to increasing physical activity among children and adults. In: Crawford D, Jeffery RW, eds. Obesity prevention and public health. Oxford: Oxford University Press, 2005:129-52.

21 Kahn EB, Ramsey LT, Brownson RC, Heath GW, Howze EH, Powell KE, et al. The effectiveness of interventions to increase physical activity: a systematic review. Am J Prev Med 2002;22(suppl 4):73-107.

22 Stone EJ, McKenzie TL, Welk GJ, Booth ML. Effects of physical activity interventions in youth. Review and synthesis. Am J Prev Med 1998;15:298-315.

23 Dishman RK, Buckworth J. Increasing physical activity: quantitative synthesis. Med Sci Sports Exerc 1996;28:706-19.

24 Bautista-Castaño I, Doreste J, Serra-Majem L. Effectiveness of interventions in the prevention of childhood obesity. Eur Epidemiol 2004;19:617-22.

25 Reilly JJ, McDowell ZC. Physical activity interventions in the prevention and treatment of paediatric obesity: systematic review and critical appraisal. Proc Nutr Soc 2003;62:611-9.

26 Muller MJ, Danielzik S, Pust S. School- and family-based interventions to prevent overweight in children. Proc Nutr Soc 2005; 64:249-54.

27 Wechsler H, Devereaux RS, Davis M, Collins J. Using the school environment to promote physical activity and healthy eating. Prev Med 2000;31:S121-37.

28 Sallis JF, Simons-Morton BG, Stone EJ, Corbin CB, Epstein LH, Faucette N, et al. Determinants of physical activity and interventions in youth. Med Sci Sports Exerc 1992;24(suppl 6):S248-57.

29 Flodmark C-E, Marcus C, Britton M. Interventions to prevent obesity in children and adolescents: a systematic literature review. Int J Obes 2006;30:579-89.

30 Resnicow K, Robinson TN. School-based cardiovascular disease prevention studies: review and synthesis. Ann Epidemiol 1997;7(suppl 7):S14-31.

31 Engbers L, van Poppel M, Chin A, Paw M, van Mechelen W. Worksite health promotion programs with environmental changes: $\mathrm{a}$ systematic review. Am / Prev Med 2005;29:61-70.

32 Ogilvie D, Egan M, Hamilton V, Petticrew M. Promoting walking and cycling as an alternative to using cars: systematic review. BMJ 2004;329:763.

33 Riddoch C), Andersen LB, Wedderkopp N, Harro M, KlassenHeggebø L, Sardinha LB, et al. Physical activity levels and pattern of 9- and 15-yr-old European children. Med Sci Sports Exerc 2004;36:86-92.

34 Fox KR, Riddoch C. Charting the physical activity patterns of contemporary children and adolescents. Proc Nutr Soc 2000;59:497-504.

35 Sallis J, Prochaska J, Taylor W. A review of correlates of physical activity of children and adolescents. Med Sci Sports Exerc 2000;32:963-75.

36 Bradley C, McMurray R, Harrell J, Deng S. Changes in common activities of 3rd through 10th graders: the CHIC study. Med Sci Sports Exerc 2000;32:2071-8.

37 Fahlman M, Hall H, Lock R. Ethnic and socioeconomic comparisons of fitness, activity levels and barriers to exercise in high school females. J Sch Health 2006;76:12-7.

38 Gordon-Larsen P, McMurray RG, Popkin BM. Adolescent physical activity and inactivity vary by ethnicity: the national longitudinal study of adolescent health. J Pediatr 1999;135:301-6.

39 Kumar BN, Holmboe-Ottesen G, Lien N, Wandel M. Ethnic differences in body mass index and associated factors of adolescents from minorities in Oslo, Norway: a cross-sectional study. Public Health Nutr 2004; 7:999-1008.

40 Gordon-Larsen P, McMurray RG, Popkin BM. Determinants of adolescent physical activity and inactivity patterns. Pediatrics 2000;105(6):E83.

41 Kristjansdottir G, Vilhjalmsson R. Sociodemographic differences in patterns of sedentary and physically active behavior in older children and adolescents. Acta Paediatr 2001;90:429-35. 
42 Lasheras L, Aznar S, Merino B, Lopez EG. Factors associated with physical activity among Spanish youth through the national health survey. Prev Med 2001;32:455-64.

43 McVeigh JA, Norris SA, de Wet T. The relationship between socioeconomic status and physical activity patterns in South African children. Acta Paediatr 2004;93:982-8.

44 Gustafson SL, Rhodes RE. Parental correlates of physical activity in children and early adolescents. Sports Med 2006;36:79-97.

45 Dowda M, Dishman RK, Pfeiffer KA, Pate RR. Family support for physical activity in girls from 8th to 12th grade in South Carolina. Prev Med 2007;44:153-9.

46 Sallis JF, Owen N. Ecological models. In: Glanz K, Lewis FM, Rimer BK, eds. Health behavior and health education: theory, research, and practice. 2nd ed. San Fransisco: Jossey-Bass, 2004:403-24.

47 Ball K, Timperio AF, Crawford DA. Understanding environmental influences on nutrition and physical activity behaviors: where should we look and what should we count? Int J Behav Nutr Phys Act 2006;3:33.

48 Veitch J, Bagley S, Ball K, Salmon J. Where do children usually play? A qualitative study of parents' perceptions of influences on children's active free-play. Health and Place 2006;12:383-93.
49 Owen N, Leslie E, Salmon J, Fotheringham MJ. Environmental determinants of physical activity and sedentary behavior. Exerc Sport Sci Rev 2000;28:153-8.

50 Ridgers ND, Stratton G, Fairclough SJ, Twisk JW. Children's physical activity levels during school recess: a quasi-experimenta intervention study. Int J Behav Nutr Phys Act 2007;4:19.

51 Froberg K, Andersen LB. Mini review: physical activity and fitness and its relations to cardiovascular disease risk factors in children. Int J Obes 2005;29(suppl 2):S34-9.

52 Pate RR, Pratt M, Blair SN, Haskell WL, Macera CA, Bouchard C, et al. Physical activity and public health. A recommendation from the Centers for Disease Control and Prevention and the American College of Sports Medicine. JAMA 1995;273:402-7.

53 Lewis BA, Marcus BH, Pate RR, Dunn AL. Psychosocial mediators of physical activity behavior among adults and children. Am J Prev Med 2002;23(suppl 2):26-35.

54 Hardeman W, Sutton S, Griffin S, Johnston M, White A, Wareham NJ, et al. A causal modelling approach to the development of theorybased behaviour change programmes for trial evaluation. Health Educ Res 2005;20:676-87.

Accepted: 11 July 2007 